Article

\title{
Company Engagement in Apprenticeships in Crisis-Hit Greece: A Critical Overview
}

\author{
Varvara Lalioti ${ }^{1, *}$, Dimitris Karantinos ${ }^{2}$ and Manolis Chrysakis ${ }^{2}$ \\ 1 Department of Social Administration and Political Science, Democritus University of Thrace, Panagi Tsaldari 1, \\ Komotini 69100, Greece \\ 2 National Centre for Social Research, Kratinou 9 \& Athinas, Athens 10552, Greece; \\ dkaradin@otenet.gr (D.K.); echrysakis@ekke.gr (M.C.) \\ * Correspondence: blalioti@gmail.com
}

Received: 25 May 2018; Accepted: 21 June 2018; Published: 25 June 2018

check for updates

\begin{abstract}
In contrast to the relatively limited attention given in the past to apprenticeships and apprenticeship-related issues in Greece, the crisis has triggered a definite interest in this area. This is largely due to the serious implications of the crisis, in conjunction with the idea that apprenticeships could be an alternative educational pathway for boosting labour market integration, an idea also promoted by EU institutions. Against this backdrop, the present article is, essentially, the first effort made to highlight, in a succinct and critical way, the crucial dimensions of an under-researched key aspect of the apprenticeships in Greece: company engagement. Drawing on the findings of a large-scale, mostly qualitative, research project (December 2015-March 2017) that reviewed apprenticeship programmes in this country, and during which, inter alia, 150 stakeholders were surveyed and an online survey was conducted with 828 employers, the article highlights the strengths characterizing company involvement in apprenticeships, but also severe shortcomings which overshadow the strengths. It is argued that there is an urgent need for restructuring. Otherwise, the potential of apprenticeships in Greece to be an alternative educational pathway to boost employment at a time of extremely high unemployment, especially for young people, will be undermined.
\end{abstract}

Keywords: vocational education and training (VET); apprenticeships; company engagement; Greece; crisis

\section{Introduction}

In Greece, the relatively limited interest shown by national authorities (and researchers) in apprenticeships and apprenticeship-related issues, such as company engagement in apprenticeships, is synonymous with the fact that the Greek vocational education and training (VET) system is historically underdeveloped. Indeed, the country's performance for many VET key indicators is low compared with the EU average, as exemplified by the share of upper secondary students enrolled in the VET system (33.7\% in 2014, as opposed to the EU average of 48.9\%) (European Commission 2015a, p. 2). Overall, this restrained interest and underdevelopment are associated with the idea that enrolment in the VET system does not lead to social and economic mobility (Paidoussi 2016).

VET is part of non-compulsory upper secondary education in Greece, which alongside compulsory lower secondary education forms secondary education in this country. Currently, the main types of VET programmes include the following: Formal upper secondary school-based VET programmes, offered at vocational education schools (known as EPAL) and run by the Ministry of Education; apprenticeship programmes, offered at vocational training schools (known as EPAS) and run mostly by the Manpower Employment Organization (OAED), the Greek public employment service that is 
supervised by the Ministry of Labour; and apprenticeship programmes offered at post-secondary level in vocational education schools (EPAL) (piloted in 2016 and expanded in March 2017). Hence, apprenticeship programmes are part of VET programmes.

The VET system's relative underdevelopment is also in line with the fact that, for decades, only one system at secondary education level in Greece that satisfied the European Centre for the Development of Vocational Training's (Cedefop) criteria for 'apprenticeship' existed. Some of these criteria are: a combination of class- and work-based learning to acquire an intermediate occupational skill; the signing of a contract between the apprentice and the employer; and the remuneration of apprentices (Cedefop 2014). This was the dual education system implemented by the OAED, which, as mentioned above, offered apprenticeship programmes at vocational training schools (EPAS). Despite the recent expansion of apprenticeship provision as an option at the post-secondary level through the EPAL, the OAED is broadly acknowledged to be the most important provider of apprenticeships in Greece. The succinct and critical overview of company engagement in the apprenticeship programmes offered by the OAED lies at the centre of the present article.

The OAED's apprenticeship system is similar to the German and Austrian system of apprenticeships. OAED is currently responsible for 51 EPAS that offer apprenticeship programmes, to students aged between 16 and 23, who must have completed at least the first class of the Upper Secondary School (Lykeio). The predecessors of EPAS were founded in 1952, when a Royal Decree established Technical Apprenticeship Schools belonging to the Ministry of Labour. More than 30 years later, Law 1346/1983 established the educational apprenticeship units of OAED. The law also enabled the OAED to be actively involved in the decisions concerning the type and duration of apprenticeships, remuneration issues, and the method of recruiting apprentices, among other aspects. Next, Law 1566/1985 signalled the integration of EPAS into secondary education. In the decades that followed, a series of legislative provisions regulated EPAS' operations. Among the most recent additions to the national legislation are Laws 4186/2013 and 4327/2015.

The EPAS provide education for two school years (four semesters). A wide range of specialties is offered, such as silversmithing, bakery-pastry, hairdressing, etc. Students attend theoretical and laboratory courses at the EPAS units for $21 \mathrm{~h}$ per week (one morning and four evenings), and undertake practical training in the workplace for a maximum of six hours per day (four, five, or six days per week). The 'on-the-job learning' component of the apprenticeship programmes takes place in private or public sector companies with terms specified in the relevant apprenticeship contract and is assumed to help the apprentices acquire work experience in actual work conditions.

The EPAS are annually attended by approximately 10,000 students, depending on the relevant annual announcement. The remuneration of the apprentice amounts to $75 \%$ of the daily minimum wage ( $€ 17.12$ per day) (as determined by the national general collective labour agreement), for all four apprenticeship semesters. The companies participating in the programme are also subsidized ( $€ 11$ per day). This subsidy may be paid either to the employer or directly to the apprentice. Apprentices acquire social insurance stamps corresponding to their years of apprenticeship as a pensionable period of service. Furthermore, upon completion of their studies, EPAS graduates receive a specialization diploma, corresponding to qualifications of level 4 of the national and European qualification frameworks.

Since the outbreak of the crisis, apprenticeships and apprenticeship-related issues in Greece have been placed at the centre of public dialogue and policy-making. Illustrative of this newly acquired interest are interventions for the restructuring of apprenticeships, such as those included in Laws 4186/2013 and 4327/2015, mentioned above, the Economic Adjustment Programme (European Commission 2015b, p. 22), the National Strategic Framework for Upgrading VET and Apprenticeship (Ministry of Education, Research and Religion 2016) and, in particular, the Quality Framework for Apprenticeships (Joint Ministerial Decision 26385/20 February 2017). These interventions will be assessed by 2021.

This recent turn should be understood in the light of the severe implications of the crisis in Greece and the related idea of apprenticeships as an alternative educational path to boost employment, a view 
also promoted by EU institutions. The former is reflected in the rampant increase in unemployment rates, especially youth unemployment, which according to Eurostat data increased dramatically from $22.7 \%$ in 2007 to $52.4 \%$ in 2014 (and then to 47.3\% in 2016), triggering an extensive brain drain.

The impact of the crisis on the EPAS apprenticeship programmes is also evident: after reaching a peak of 20,360 between 1999 and 2000, the number of apprenticeship positions shrunk between 2014 and 2015 to $10,374 .^{1}$ This is an outcome of the decreasing amount of funds available for apprenticeships, the diminishing financial capacity of companies, especially SMEs, to offer apprenticeship positions and, to a lesser extent, the reduction in duration of the EPAS apprenticeship programmes from three years to two from 2006 onwards. The reversal in the number of positions offered by private and public companies is an additional sign of the relative decline of apprenticeships in crisis-ridden Greece. Whereas between 2001 and 2008 66\% of the apprenticeship positions were located in the private sector and the remaining $34 \%$ in the public sector, since $200966 \%$ have come from the latter and $34 \%$ from the former.

At the same time, as mentioned above, graduation from apprenticeship programmes is believed to improve transition to the labour market. Indeed, past research on this subject indicated relatively high percentages of labour market access for apprenticeship graduates, a finding that a more recent study conducted by the Ministry of Labour, Social Insurance and Welfare corroborates: approximately $50 \%$ of the EPAS graduates included in the research sample ${ }^{2}$ managed to find a job within six months of completing their studies. The idea of apprenticeships as an alternative educational pathway that boosts employment is in line with the central position apprenticeship programmes occupy in the discussion about the restructuring of education in Europe as a means of attaining better socio-economic results. According to EU data, at the European level, 60-70\% of apprentices move into a job directly following their studies, and in some cases this increases to $90 \%$ (European Commission 2017). For this reason, the EU has developed a range of tools to promote apprenticeships, such as the European Alliance for Apprenticeships, launched in 2013, and the European Framework for Quality and Effective Apprenticeships, adopted by the European Council in 2018.

Against this backdrop, apprenticeship programmes in Greece, including company engagement, are extremely under-researched and, more often than not, examined in the context of the country's VET strategy (see, e.g., Georgiadis 2014; Paidoussi 2014, 2016, for some recent additions to the respective literature stream). Additionally, although the newly acquired interest in apprenticeships in crisis-ridden Greece started paving the road for studies focusing exclusively on apprenticeship programmes (e.g., Foundation for Economic and Industrial Research 2015; Ministry of Labour, Social Insurance and Welfare 2015), references to company involvement remain few and far between.

Those that are found in the aforementioned studies include data on the regional distribution of companies offering apprenticeship positions and on the economic sector they are involved in. The central arguments formulated in the context of this literature are: first, that companies face crisis-driven difficulties that limit their ability to offer apprenticeships at the same time making it clear, however, that participation in apprenticeship programmes should not be perceived by employers as a means of reducing labour costs; and, second, that the limited company engagement in the EPAS apprenticeship system should come to an end.

There are one or two rare cases of studies that exclusively discuss company involvement in apprenticeship programmes, highlighting the problems characterizing company engagement. One such is the 2017 study conducted by the Small Enterprises Institute of the Hellenic Confederation of Professionals, Craftsmen and Merchants that reviews the main conditions determining the participation of SMEs in apprenticeships and the standards required. A main problem identified is the lack of a broad range of incentives, not solely financial, that would motivate companies to offer apprenticeship

This and the next paragraph draw on the (Ministry of Labour, Social Insurance and Welfare 2015, pp. 13-15, 31, 43-44). A random sample of 700 graduates. The total population of EPAS apprenticeship graduates for the academic years 2011-2012, 2012-2013, and 2013-2014 was 13,846. 
positions. Furthermore, one of the aims of a project that took place between 2014 and 2017 under the lead of OAED with the engagement of social partners and the Institute of Educational Policy was to investigate the role of companies as sustainable partners in apprenticeships in Greece (and Cyprus).

The underdevelopment of the literature concerning company involvement in apprenticeships in Greece, although leaving ample scope for research, contrasts with the broad examination of the subject in other countries. The respective bibliography covers a wide range of topics and recent examples include the following: the level of engagement of employers (Shury et al. 2012); company motivation in offering apprenticeship positions (e.g., Muehlemann and Wolter 2014; Pfeifer 2016); the challenges faced by employers in managing apprentices in the workplace (e.g., Rowe et al. 2017); and also more 'comprehensive' accounts of company engagement in the apprenticeship system, as exemplified by employers' opinions on the subject, such as the one offered by Winterbotham et al. (2012).

Within this literature, various arguments have been formulated. Hence, although the overall level of employers' engagement in the apprenticeship system is regarded as relatively low, involvement (and employer satisfaction) appear to vary by sector and employer size. It seems that promoting apprenticeships as advantageous may sometimes be offset by factors such as employers becoming increasingly suspicious about quality the more they see apprenticeships being pushed in the media. Participation in apprenticeship programmes is considered to bring real benefits to companies, such as providing skilled workers for the future and rejuvenating their current workforce. Barriers to company engagement, especially for SMEs, are thought to include the lack of apprenticeship-related information, the administrative burden and, also, although to a lesser extent, the financial burden imposed on companies. Employers appear to be sensitive to costs, but the idea of sharing most of the costs of apprenticeships between themselves and the state does not necessarily put off employers from engaging in apprenticeship programmes (for a review see, e.g., Gambin 2013, pp. 15-27).

Building on the above and seeking, thus, to contribute to filling a significant gap in the apprenticeship-related literature as far as Greece is concerned, the present article offers a review of key dimensions of company involvement in the EPAS apprenticeship programmes, which, as mentioned, remain the most recognisable providers of apprenticeships in Greece. The discussion takes place in accordance with the following analytical categories highlighted by the research: the rights and obligations of companies participating in apprenticeship programmes, including minimum requirements for company engagement; strategies and initiatives for marketing apprenticeships and informing companies about their benefits, including the role of employer organizations; and constraining and enabling factors in relation to engaging employers in apprenticeships, including non-financial support and recognition for those companies providing quality apprenticeship programmes. We argue that, despite important strengths, company engagement in apprenticeship programmes in Greece is characterized by serious shortcomings, which undermine their effectiveness, and we suggest restructuring.

\section{Research Methodology}

The data and research findings draw on a large-scale, mostly qualitative research project carried out between December 2015 and March 2017, which was aimed at reviewing apprenticeships in Greece, in accordance with the 10 thematic areas covered by Cedefop's analytical framework for apprenticeships. These ranged from the place of apprenticeships in the national VET system to labour market responsiveness, and included participation of and support available for companies (Cedefop 2015).

Each one of these thematic areas contained a number of sub-issues. In the case of company engagement in apprenticeships these were the following: Are the rights and obligations of companies participating in apprenticeships legally stipulated? Do strategies and initiatives exist for marketing apprenticeships and making information available to companies about the benefits of taking apprentices, as well as on their related responsibilities and any incentives available to encourage their involvement? Should there be minimum requirements for companies willing to provide apprenticeship 
positions and/or an accreditation procedure? Should companies, especially SMEs, receive non-financial support for implementing apprenticeships? Should there be some sort of recognition, perhaps even an award, for companies that provide quality apprenticeship positions? Finally, should employer organizations play a key role in engaging and supporting companies?

After undertaking extensive desk research on the state of apprenticeships in Greece, a total of 150 individuals, representing different groups of stakeholders, were surveyed in three consecutive rounds. The sampling method for the selection of interviewees involved a three-stage process: identification of regions and distribution of the number of interviews across regions; distribution of interviews with company representatives across economic sectors; and distribution of interviews across target groups. We safeguarded the participants' identity by promising them confidentiality, in the sense that their identity was known to us but protected from public exposure.

The first round (between April and June 2016) was targeted at collecting factual information concerning the implementation of apprenticeships. In this round, we carried out 100 semi-structured interviews (with 27 students, 15 recent graduates, 23 teachers and school directors, 33 company representatives, and 2 OAED employees). This stage concluded with a round table, in which social partners, ministries and other national agencies engaged in apprenticeships were represented.

The second round (between September and October 2016) was targeted at discussing the challenges identified in the previous round, as well as the current and future role of the institutions involved in apprenticeship programmes. Building on the findings of the first round, the second round comprised 35 semi-structured interviews (with 22 representatives from national agencies engaged in apprenticeships, 11 representatives from social partners and 2 VET and apprenticeship experts). This stage concluded with an online survey of 828 companies, and a round table focusing on topics that arose during the interviews, in which a selection of representatives from the main stakeholder groups interviewed participated.

The third and final round (between January and February 2017) was aimed at examining possible solutions and recommendations for the improvement of apprenticeships in Greece. It included five semi-structured interviews (with three policy-makers, one representative from social partners and one VET and apprenticeship expert) and two round tables. The first round table gathered together representatives from social partners and chambers of commerce and industry, whereas the second was composed of representatives from ministries and national agencies involved in apprenticeships.

Company involvement in apprenticeships, the focus of the present article, was examined mostly in the first survey round and in the online survey with employers. The questionnaires utilized in this round differed slightly for interviewees from different groups in line with the various roles of these groups in apprenticeships. For example, questions addressed to school directors and teachers with regard to company engagement in apprenticeships included whether companies took their responsibilities seriously, the initiatives schools took to attract companies, and if they believed that companies were satisfied with the level of knowledge of apprentices. Amongst the questions directed to employers were if they had received support from schools, what the main advantages of apprenticeship programmes were, and what kinds of incentives with regard to participation they valued the most.

The online survey with employers was launched on 6 November 2016 and closed on 6 December 2016. Employees of the OAED IT Directorate forwarded the invitation letter for the survey to 21,847 companies, eventually reaching 19,153 of them. The list of companies utilized was provided to us by OAED and included both companies with previous experience in apprenticeship programmes and those who had none. Unsurprisingly, given the extremely high number of SMEs in Greece, which according to Eurostat data for 2015 constituted $99.9 \%$ of all companies, they constituted $98 \%$ of the sample.

The questionnaire for the online survey, completed by a total of 828 companies, covered the following topics: whether employers would be willing to take apprentices; the kind of apprentices they would be willing to take and the conditions under which they would be willing to take them; 
the potential contribution of companies to apprenticeships; the financial and non-financial support needed for them to decide to participate; and factors hindering company engagement.

Finally, as mentioned above, the questionnaires for the second and third survey rounds, which were identical for all groups of interviewees participating in these rounds, addressed issues associated with company involvement in apprenticeships only to a small degree. Questions were asked on subjects including: possible actions that would improve companies' perception of apprenticeship-related benefits and the potential role of national agencies and social partners in this respect; strategies to increase companies' trust in apprenticeships; and additional incentives that would attract companies to participate in apprenticeships.

\section{Research Results: Crucial Dimensions of Company Engagement in Apprenticeships}

\subsection{Rights and Obligations of Companies Offering Apprenticeship Positions}

More than nine-tenths of the interviewees from all groups of stakeholders agreed that at least some of the rights and obligations of employers are legally stipulated. Illustrative of this is the following extract from an interview with an OAED employee:

According to Article 27 of the Joint Ministerial Decision no. 40087/14 December 2007, employers have, inter alia, the legal obligation to implement the work-based component of apprenticeship programmes, comply with strict rules for the safety and protection of apprentices, and cancel the apprenticeship contract, if the apprentice interrupts her/his studies or is not consistent with her/his obligations during work-based training. In a similar vein, the national legislation, as exemplified by Articles 1 and 2 of the Joint Ministerial Decision no. 29502/85/01 September 2014, includes information on the companies' financial contributions and administrative obligations.

Furthermore, there is a general consensus amongst interviewees that the rights and obligations of employers are clear, mainly in terms of the working conditions for apprentices and the economic responsibilities of companies. However, an area in which they are not clear is the content of work-based learning, whose ad hoc nature stands out as a key problem for the quality of training at the company level.

As one of the EPAS teachers mentioned:

The existence of relatively explicit rules governing, in particular, the conditions in the workplace and the economic responsibilities of companies contrasts with the overall absence of a detailed plan for company-based learning. Such a plan would significantly improve the standards and the quality of apprenticeship programmes. However, in practice, much is decided ad hoc.

As mentioned above, although this information is broadly confirmed from the interviews with representatives from all groups of stakeholders, approximately $80 \%$ and $10 \%$ of interviewees, respectively, underlined, first, the role played by work-based learning, often delivered by the head of the company acting as the in-company trainer, and, second, that there were exceptions when it came to the usual lack of a learning plan. Thus, in the words of an apprentice:

Although my impression is that he did not follow a specific plan, the head of the company helped us to learn the basics of our profession. This is something that appears to happen more in extremely small companies. In other cases, the head of the company usually assigns the head of a department as responsible for the work-based training of apprentices.

Further, as mentioned by an SME employer:

There is no document describing what apprentices should learn at the company level. The training of apprentices takes place in an ad hoc way, in accordance with the nature 
of company activities and its needs. Of course, there are exceptions. These may be found especially in the case of companies that operate under franchising, where the 'mother company' applies a specific plan of training for all employees. Apprentices are not excluded from that plan. Exceptions may also be found in the case of large companies that offer apprenticeship positions.

Yet, against this backdrop, fortunately, it appears that the majority of companies offering apprenticeship positions adhere to their responsibilities. Otherwise, the apprenticeship contract may be broken. This finding is corroborated by over $90 \%$ of the teachers and OAED employees and $80 \%$ of the apprentices and recent graduates. Illustrative of this are the words of a teacher, who also points out the existence of exceptions:

When companies do not comply with their responsibilities, apprentices may be placed in another company. Furthermore, these companies are (informally) put on a black list and we avoid future collaboration with them. Certainly, there are also cases of employers, who violate particularly the time schedule of apprentices and others, especially in the public sector, who tend to utilize apprentices in ways that do not match with their specialty.

More than half of the employers interviewed complained about the work pattern of apprenticeship programmes, claiming that it needed to become more flexible to conform with the needs of companies, both on an ad hoc and a permanent basis. Following on from this, approximately two-tenths of the apprentices and graduates interviewed reported a bad experience with an employer, especially if they had been forced to fulfil tasks that were not compatible with their specialty. As one of the graduates mentioned: 'I was supposed to be responsible for taking care of the infants at the nursery. Instead, the boss made me clean the kitchen and prepare coffee for the other employees.'

More than eight-tenths of interviewees from all groups of stakeholders believe that such problems are associated with the essential lack of clear-cut and explicit guidelines as to minimum requirements for companies willing to offer apprenticeship positions, highlighted by our research as one of the negative features of apprenticeships. Differing views have been expressed, mainly by employers and social partners representing large companies. The following extract from an interview with a social partner is revealing:

Certainly, we agree that some minimum requirements for companies willing to offer apprenticeship positions should be stipulated. This could include, for example, making mandatory the use of in-company trainers. Our organization is willing to help in this direction, as far as safeguarding the aforementioned requirements is concerned; however, the ability of companies to be flexible must not be jeopardized by requirements.

What happens in practice is that the selection of companies is based on a series of quite informal actions, and this is agreed with by over $90 \%$ of the interviewees from all the groups of stakeholders. Because these actions occur on a regular basis, they have become quasi-institutionalized. Illustrative is the following extract from an interview with an OAED employee:

The selection of companies to participate in apprenticeship programmes is based on: the labour market research conducted by the EPAS and the teachers themselves; meetings (held usually in May and attended by representatives from the EPAS, social partners and chambers); and the development of personal networks between the EPAS teachers and employers. Finding companies to provide workplace training for apprentices is a responsibility of the EPAS. The newly created EPAS Career Offices have lately also been playing a key role in the selection of companies, and in a more organized way than in the past. They are responsible for matching apprentices and training posts in the workplace, after taking into account the apprentice's performance at school, as well as geographical and social criteria. The opinion of the teacher in charge of the specialty on the most suitable options for the apprentices is of critical importance. 
Our research compiled a long list of suggestions made by interviewees for improving the landscape with regard to the rights and obligations of companies offering apprenticeship positions. These included: introducing explicit rules for learning agreements governing company-based learning; the necessity of close cooperation between all the actors engaged in apprenticeships, such as ministries, social partners, local associations, and representatives thereof; setting minimum requirements for company engagement in apprenticeships, such as being in a healthy financial state and being in operation for at least five years; and introducing an accreditation procedure as a means of improving the overall standards of companies involved in apprenticeships.

\subsection{Strategies and Initiatives with Regard to Marketing Apprenticeships and Informing Companies about Their Benefits}

There was a general consensus amongst interviewees from all groups of stakeholders that personal relationships between teachers, school directors, OAED employees, employees at OAED Centres for the Promotion of Employment (KPA) and employers are a major, if not the main instrument utilized to market apprenticeships and inform companies about their benefits. These should be viewed in conjunction with the less frequent, more 'formal' attempts to advertise apprenticeship programmes. The following extract from an interview with a school director is revealing:

The development of personal relationships between all those involved in the EPAS apprenticeship system is key to the effort to promote apprenticeships and inform companies about their benefits. There are several occasions that provide us with the opportunity to develop such relationships. For instance, at the end of each school year the EPAS directors, in cooperation with teachers, contact employers and inform them about the specialties offered and the apprentices available for apprenticeship placements. At the same time, OAED has also undertaken some more systematic initiatives to boost apprenticeships. A good, relatively recent example is the launch of a publicity campaign in November 2015 to link apprenticeships with society and the labour market. The campaign utilized the radio and social media, but also events and workshops with local employers and stakeholders, as means to advertise apprenticeship programmes. The existence, however, of an overall national strategy to promote apprenticeships is, unfortunately, doubtful.

Furthermore, it appears that, overall, in practice, the actions taken to market apprenticeships and inform companies about their benefits are, to a large extent, ineffective. Illustrative of this is the fact that, according to the online survey, less than $30 \%$ of employers were aware of the apprenticeship programmes offered by OAED. Moreover, on the question of what additional non-financial support companies need in order to increase the offer of apprenticeship placements, the top answer amongst employers in the online survey was that they want more and better information on the benefits and costs of apprenticeships, as well as on the procedures for employing an apprentice, thus confirming the serious information gap.

Similarly, the interviews indicated that only one-fifth of the employers understood the benefits of apprenticeships. Companies only have access to limited information about apprenticeship programmes and this is confirmed by approximately two-tenths of interviewees from all groups of stakeholders.

Our research showed that effective communication between the EPAS and companies is hindered by the operational shortcomings of actors who have an institutional role in apprenticeships, such as KPA. Illustrative of this is the extract from an interview with a teacher:

Although OAED does not apply, through KPA, a special programme to inform employers about apprenticeships, KPA officers, similarly to school directors and teachers, in practice develop personal relationships with employers and discuss with them the benefits of taking apprentices. Nonetheless, there are serious limitations in the role of KPA in marketing apprenticeships. Above all, KPA suffer from understaffing, as well as from hiring inexperienced employees. 
The minimal role played by employer organizations in engaging and supporting companies is an additional reason why there are limitations on marketing apprenticeships. As a teacher mentioned:

Although we take many initiatives to market apprenticeships and inform companies about the benefits of taking apprentices, only a few employers understand, in reality, the advantages of offering apprenticeship positions. One of the main reasons for this is that chambers and professional associations do not try to be more informed about apprenticeships, so as to pass this information to their members.

Indeed, the minor role played, in particular, by employer and professional organizations in informing companies about apprenticeships, but also more generally in engaging and supporting companies, is highlighted in the interviews by more than $80 \%$ of the employers. In the words of one company representative:

To the best of my knowledge, companies participating in apprenticeship programmes have not received any kind of support, or in the best-case scenario received minimal support, from their professional association or other organization representing employers. This includes limited information about the advantages and disadvantages of apprenticeship programmes.

As with most things, however, there are exceptions. These were noted in interviews with representatives from large companies, as reflected in the following comment from a director of a company active in the tourist sector:

During previous years, the Hellenic Chamber of Hotels, alongside the Greek Tourist Confederation, has played a key role in supporting us. This includes informing us about apprenticeship programmes, and also letting state authorities know about the problems we face in the implementation of the company-based component of these programmes.

On the other hand, the interviews with representatives from social partners and especially with representatives from chambers of commerce and industry indicated that there was a general agreement amongst these actors that they needed to offer more information to companies regarding the benefits and costs of apprenticeships and, generally, to become more engaged in the various stages of apprenticeship programmes.

Overall, almost half of the interviewees from all groups of stakeholders argued that improving the overall quality of apprenticeships per se, as reflected in the standards for learning and the competencies apprentices are expected to develop, is the best possible communication strategy for the promotion of apprenticeships. Such improvements should be viewed in conjunction with the design of a clear-cut national strategy to boost apprenticeships. Additional suggestions made by interviewees were: extending the use of careers services at the secondary and post-secondary levels; and enhancing not only the role of chambers of commerce and industry, and employer and professional organizations, but also employees, in informing companies about the costs and benefits of apprenticeships and the positions available.

\subsection{Constraining and Enabling Factors in Relation to Engaging Employers in Apprenticeship Programmes}

Although more than two-thirds of the employers interviewed agreed that their financial contribution to the cost of apprenticeships is not high, the same percentage argued that if participation had no cost for them (or had a lower cost), offering apprenticeship positions would become more attractive. Illustrative of this are the words of one of the employers interviewed:

I own a small company and have difficulties in paying my share. Personally, I have no doubt that being exempted from funding part of the wage and social insurance contributions of apprentices would be a strong incentive to take them on. 
Furthermore, despite the general agreement that they would be open to non-financial incentives, such as gaining publicity for offering apprenticeship positions, the simplification of administrative procedures and being offered inducements to hire apprentices upon completion of the programme, more than $90 \%$ of the employers interviewed mentioned that the introduction of such incentives would not compensate them if their contribution to apprentices' wages was to increase.

In a similar vein, less than one-tenth of employers indicated that they would hire an apprentice without financial support. There were a few exceptions found in large private companies, whose representatives argued that they would still offer apprenticeship positions even without financial incentives, meaning the sharing of costs between the government and companies. Non-financial incentives appear to be of far more worth to such companies than to SMEs. The following extract from an interview with the representative from a large company in the tourist sector is revealing:

In a time of severe crisis, the financial incentive for participation in the EPAS apprenticeship system is much stronger for SMEs than for large companies, as ours. In our case, even without financial support, which by the way we consider to be quite low, we would continue to take on apprentices. The reason is that the EPAS offer specialties, which are necessary for our company, and difficult to find otherwise. In fact, in the case of the state offering us non-financial incentives to participate in apprenticeships, we would be willing to pay a higher contribution to the wages of apprentices.

The significance of the financial incentive as the most crucial enabling factor for company engagement in apprenticeship programmes is confirmed by the online survey: when asked to reveal the important benefits ${ }^{3}$ of an apprenticeship in comparison with other training schemes, the top answer given by employers was that apprentices cost less than the alternatives. Likewise, in another question addressed to participants in the online survey, the lower wage bill stood out as the main benefit of apprenticeship programmes. Therefore, employers largely admit that taking on apprentices results in a reduction in labour costs.

However, at the same time, approximately half of the employers interviewed expressed a positive view on the added value of apprentices. In the words of one of the employers interviewed:

I see apprentices as young people with fresh ideas who can greatly contribute to innovation, increase productivity and reduce production costs. Moreover, in my opinion, apprentices can more easily adapt and are devoted to the company culture. Overall, they identify with the company in a better way than older individuals do.

Indeed, next to the low cost of apprentices, the second most important feature of apprenticeship programmes mentioned by participants in the online survey was the young age of apprentices and, thus, their ability to better adapt to company needs. Other benefits of apprenticeships highlighted in the online survey included the fact that apprentices could be trained as future staff, their higher productivity, and their contribution to improving the company image.

Interviews with other groups of stakeholders confirm the above findings. For instance, more than $90 \%$ of the teachers and school directors interviewed believe that one of the major reasons companies offer apprenticeship positions is that they view them as an investment in new, young employees that will help them make production more cost-effective.

Moreover, interestingly, a small proportion of interviewees (less than 20\%), especially from groups representing school directors and teachers, and social partners, argued that a specific learning plan for work-based training would act as a counterincentive for companies to offer apprenticeship positions. In the words of a school director:

3 In this and the following cases that refer to the online survey, participants were given the chance to provide multiple answers. 
Although I am afraid that the lack of a specific plan for the company-based component of apprenticeship programmes may decrease the quality standards of training, its existence may make employers more negative with regard to being part of the EPAS apprenticeship system.

In a similar vein, more than half of the employers interviewed fear that setting out detailed requirements for a specific plan governing company-based learning could enhance the negative attitude of employers with regard to offering apprenticeship positions.

At the other end of the spectrum, our research underlined the general consensus, especially amongst employers, but also amongst other groups of stakeholders, such as OAED employees, on the negative effects of the socio-economic context on companies' interest in taking on apprentices. As the owner of an SME argued:

For very small companies like mine, the crisis has made it more difficult to employ people outside the family circle and, thus, to take on apprentices. Overall, in my opinion, the crisis has resulted in a fall in the demand for apprenticeships.

Likewise, in the words of an OAED employee:

I believe that companies are expected to increase their interest in the EPAS apprenticeship system and offer more positions, only in a time of development. In contrast, the crisis has significantly restrained the ability of SMEs, that is the overwhelming majority of companies in Greece, to take on apprentices.

Furthermore, approximately three-tenths of interviewees from all groups of stakeholders agree that additional factors hindering company engagement in apprenticeship programmes are high administrative costs and slow bureaucratic procedures. In the words of one of the employers:

My personal experience with OAED makes me believe that the EPAS apprenticeship system suffers from slow and complex administrative procedures. Another problem is that, in this context, accountants ask for additional remuneration in order to deal with the work resulting from the inclusion of apprentices on staff lists; which has a further impact on SMEs deciding whether to hire an apprentice or not.

Building trust in apprenticeships also takes time, mainly due to the lack of information as highlighted in the previous subsection. As another employer mentioned, 'It takes time to build a relationship of trust between the EPAS and companies. A key reason is that employers do not have sufficient information about apprenticeship programmes.' Additionally, in the words of a school director, 'some professional associations, such as the one for bakers, essentially are not willing to collaborate with the EPAS'.

Similarly, two-tenths of the employers interviewed mentioned the, arguably, limited support received from the EPAS as another factor working against company engagement in apprenticeships. In reality, only a few employers were satisfied with this support. As one employer mentioned, 'Being myself a former apprentice, I had a very good relationship with my teachers and the school director. For this reason, I directly approached them to get apprentices.' Nonetheless, only approximately $20 \%$ of the employers took such an initiative of their own accord.

An additional constraining factor with regard to company engagement in apprenticeships, mentioned by about half of the employers interviewed, is that the school-based component of apprenticeship programmes only partly prepares apprentices for the competencies required at the company level. This is a finding confirmed by the online survey, according to which the lack of necessary skills is the main reason employers do not intend to offer apprenticeships in the future ( $9 \%$ of the sample).

Other reasons for not offering apprenticeship positions included the fact that apprentices tended to leave the company after their training, and the inability to cover the wages and/or the social security contributions of apprentices. On the question of what additional non-financial support companies 
need in order to offer (more) apprenticeship placements, top answers from employers participating in the online survey, aside from the need for better and more information on apprenticeships mentioned in the previous subsection, included apprentices with better competencies, as well as the right to select apprentices, related to the latter.

Finally, the vast majority of interviewees, employers included, agreed that recognition and reward for quality apprenticeships would provide an additional incentive for company engagement in apprenticeship programmes. Illustrative of this are the words of an OAED employee:

The state should recognize the offer of quality apprenticeship positions and provide the companies offering these positions with incentives to continue doing so. Examples of such incentives could be providing them with the right to choose apprentices first, get the best apprentices, etc. Additionally, these companies could get extra points to participate in other programmes offered by the Ministry of Labour.

Indeed, less than one-tenth of all interviewees argued that recognition and reward for quality apprenticeships should be not prioritized. A social partner representing large companies belonged to this minority:

Rewarding companies offering quality apprenticeship positions is not the best means to convince them to participate in apprenticeship programmes. In contrast, improving the standards of school-based learning is a strong tool to achieve this. Likewise, we consider as more important providing further flexibility to companies in their collaboration with the EPAS.

The suggestions made by interviewees included the consideration of new incentives, both financial and non-financial, such as reducing tax payments and social insurance contributions, the possibility of recruiting outstanding apprentices after the successful conclusion of their training, and rewarding exceptional performance. Others advocated utilizing the so-called ERGANI platform, the operational system of the Ministry of Labour that collects statistical data on labour market trends, as a tool to provide a statistical overview of the positions offered by companies, taking measures to encourage relationships of mutual trust between the EPAS and employers and, possibly, making the work pattern of apprentices at the company level more flexible (e.g., by regulating hours in the case of seasonal work, etc.).

\section{Discussion}

Our research revealed a series of strengths and weaknesses concerning company engagement in the EPAS apprenticeship system in crisis-ridden Greece. Amongst the strengths highlighted are: the legal stipulation of the rights and obligations of companies offering apprenticeship positions, although this is only partially iterated; the fact that most companies take their responsibilities seriously; the availability of financial incentives for companies; and the existence of channels of collaboration, albeit mostly 'informal', between school units and employers.

The long list of weaknesses appears to overshadow strengths, however. Shortcomings with regard to company engagement in apprenticeships include: the lack of a specific learning plan for company-based learning; the absence of a clear-cut strategy to boost apprenticeships and inform companies about their benefits; the minimal support provided to employers by employer and professional organizations; and a series of other factors hindering company involvement in apprenticeship programmes, including slow administrative procedures and the lack of recognition for companies offering quality apprenticeship positions.

Our research findings corroborate some of the central arguments made by the respective literature in Greece and, in the main, by other countries. Amongst other things, the relatively low level of company engagement in apprenticeship systems, as well as the fact that companies stand to benefit considerably from apprenticeship positions, are confirmed. 
Severe weaknesses, such as the lack of apprenticeship-related information, the administrative burden, and, to a lesser extent, the financial burden imposed on companies, also emerge. Companies face crisis-driven difficulties that restrain the offer of apprenticeships and the vast majority of companies in Greece are not willing, as are companies in other countries, to increase their contribution towards funding apprentices.

Furthermore, the suggestions made by interviewees and briefly described in the present article underline the significance of targeted policy interventions for improvements in company engagement in apprenticeships in Greece. Illustrative of these are the introduction of explicit rules governing company-based learning, setting minimum criteria for the selection of companies and the consideration of new incentives to attract companies.

Our research, which is based on an extensive review of apprenticeships in crisis-ridden Greece, presents for the very first time crucial dimensions of company involvement in apprenticeship programmes, and a wealth of results has been produced. Apparently, however, despite the originality and novelty of this research, it is not without limitations. To a large extent, these are associated with the restrictions characterizing qualitative research, in particular interviews, because these are dependent on respondents' accuracy.

Additional limitations are the relatively small proportion of employers who completed the online survey, and, importantly, the potential for generalizability of the research findings. Indeed, these are relevant only to the Greek case. Hence, their comparability with research outcomes concerning company engagement in the apprenticeship systems of other countries requires sampling to be carried out in these countries too.

Yet, the validity of the findings is secured by the measures taken for the careful distribution of a somewhat high number of interviewees across regions and across different groups of stakeholders. Overall, the results summarized may form a crucial baseline for the future evaluation of dimensions of the subject examined here, especially in the light of national and EU authorities acquiring a new interest in apprenticeships. To this end, researchers could benefit from the tools utilized in the framework of our research, such as the questionnaires designed for the groups of stakeholders participating in the three survey rounds or the online survey addressed to employers.

Building on the above, further research could aim, for example, at exploring the possible effects of recent policy developments on the rules governing company engagement in apprenticeships in Greece, as reflected mostly in the 'Quality Framework for Apprenticeships', adopted in 2017. Although at first glance it appears that there are improvements, as exemplified by the promises of establishing non-financial support for companies participating in apprenticeship programmes and creating a register of companies certified by chambers of commerce and industry for their ability to offer quality apprenticeship positions, the very first insights into these developments emphasise that, by and large, the severe problems highlighted by our research, briefly presented here, remain (see, e.g., Small Enterprises Institute of the Hellenic Confederation of Professionals, Craftsmen and Merchants 2017).

Aside from the possibility that the promise of improvements may be undermined by the weak administrative ability of the Greek state and the notoriously slow pace of reform in the country, the criticism formulated is in relation to the continuing failure to promote a coherent and coordinated strategy to enhance company engagement in the apprenticeship system, and about the absence of a framework of benefits, which could include the possibility of companies offering apprenticeship positions receiving priority in other programmes taking place under the aegis of the Ministry of Labour. Moreover, as long as financial incentives represent the key factor for company involvement in apprenticeship programmes in Greece, concerns that companies may see the expansion of apprenticeships as a means of 'cheap labour' to reduce labour costs remain valid.

Finally, further research could highlight the ways apprenticeships in other countries could be utilized as a role-model so as to improve the quality of apprenticeships in Greece. Overall, we should keep in mind, first, that the EPAS apprenticeship system bears many similarities with the German and Austrian apprenticeship systems, and, second, that the transfer of best practices is characterized 
by severe limitations. These are aspects are posed by national contexts and dynamics, as well as domestic particularities.

Yet, under the aegis of supranational institutions, such as Cedefop, the restructuring of apprenticeships in different countries appears to be governed by identical or similar principles. These include enhancing communication, cooperation, and coordination amongst all actors, ensuring that companies have suitable mentors, and developing a sustainable model of incentives for employers that will be accompanied by non-financial support. Evaluating the incorporation of these principles in different apprenticeship systems leaves ample space for investigation.

\section{Conclusions}

The growing interest in apprenticeship-related topics in crisis-ridden Greece is largely due to the severe implications of the crisis. There have been consequences for the EPAS apprenticeship system itself, the main provider of apprenticeship programmes in Greece. Furthermore, the related idea of apprenticeships as an alternative educational pathway to boost labour market integration, something also promoted by EU institutions, has come to the fore. Against this background, drawing on data from a large-scale, mostly qualitative research project that utilized Cedefop's analytical framework for apprenticeships and was aimed at reviewing apprenticeships in Greece, the present article is, essentially, the first effort made to offer a critical and succinct overview of the crucial dimensions of company engagement in apprenticeships.

Seeking to fill in a significant gap in the literature, the article highlights a series of strengths, such as the existence of financial incentives as a means of convincing employers to become engaged in apprenticeship programmes. Nonetheless, weaknesses appear to overshadow strengths, as exemplified by the absence of a clear-cut strategy to boost apprenticeships and inform companies about their benefits. Hence, our research stresses the need for improvements in the framework for company engagement in apprenticeships in Greece, after also taking into account suggestions made by interviewees, such as strengthening the role of employer organizations.

Building on the above, future research is expected to shed light on the ways practice from other countries may be applied to apprenticeships in Greece, as well as on the possible impact of the very recent policy developments concerning company engagement in apprenticeships, which, at first glance, appear to be promising, but quite limited. In this context, the drastic, timely and, more importantly, effective restructuring of the rules governing company engagement in apprenticeships in crisis-hit Greece is necessary. Otherwise, a crucial dimension of apprenticeship programmes, presently in need of urgent remedy, will be undermined, therefore risking the overall potential of apprenticeships to be the alternative educational pathway to labour market integration that national and EU authorities wish them to be.

Author Contributions: Investigation, V.L. and M.C.; Project administration, D.K.; Supervision, D.K.; Writing-Original Draft, V.L.; Writing—Review \& Editing, V.L.

Funding: This research was funded by Fondazione Giacomo Brodolini and CEDEFOP.

Conflicts of Interest: The authors declare no conflict of interest.

\section{References}

Cedefop (European Centre for the Development of Vocational Training). 2014. Developing Apprenticeships. Briefing Note. Thessaloniki: Cedefop.

Cedefop (European Centre for the Development of Vocational Training). 2015. Making Apprentices Work for Small and Medium Enterprises. Briefing Note. Thessaloniki: Cedefop.

European Commission. 2015a. Education and Training Monitor 2015. Greece. Luxembourg: Publications Office of the European Union. 
European Commission. 2015b. Memorandum of Understanding between the European Commission Acting on Behalf of the European Stability Mechanism and the Hellenic Republic and the Bank of Greece. Available online: https: / / ec.europa.eu/info/sites/info/files/01_mou_20150811_en1.pdf (accessed on 25 June 2018).

European Commission. 2017. Commission Adopts Initiative to Boost Apprenticeships in Europe. Press Release. Brussels: European Commission.

Foundation for Economic and Industrial Research. 2015. Deliverable 2. Apprenticeship Systems in Greece and Europe and Their Funding Dimension. Terms, Preconditions, Scenarios for the Expanded Participation of the Private Sector. Athens: Foundation for Economic and Industrial Research. (In Greek)

Gambin, Lynn. 2013. Review of Apprenticeships Research -Final Report: An Updated Review. Coventry: Institute for Employment Research, University of Warwick.

Georgiadis, Nikos. 2014. From School to Work. How Are Vocational Education, Training and Employment Related? Athens: Friedrich Ebert Stiftung.

Ministry of Education, Research and Religion. 2016. National Strategic Framework for Upgrading VET and Apprenticeship. Athens: Ministry of Education, Research and Religion. (In Greek)

Ministry of Labour, Social Insurance and Welfare. 2015. Support for the Implementation of Actions for the Upgrade of OAED's Apprenticeship. OAED's Apprenticeship: Trends, Evolution, Prospects, Reform of Apprenticeships. Athens: Ministry of Labour, Social Insurance and Welfare. (In Greek)

Muehlemann, Samuel, and Stefan C. Wolter. 2014. Return on investment of apprenticeship systems for enterprises: Evidence from cost-benefit analyses. IZA Journal of Labor Policy 3: 25. [CrossRef]

Paidoussi, Chrysa. 2014. Dual System of Vocational Training: The German Narrative Regarding the Connection between Education and the Labour Market. Articles and Studies 10/2014. Athens: Institute of Labour and Human Resources. (In Greek)

Paidoussi, Chrysa. 2016. Attractiveness of Vocational Education: Social and Gendered Dimensions. Articles and Studies 11/2016. Athens: Institute of Labour and Human Resources. (In Greek)

Pfeifer, Harald. 2016. Firms' Motivation for Training Apprentices: An Australian-German Comparison. Adelaide: National Centre for Vocational Education Research.

Rowe, Lisa, Daniel Moss, Neil Moore, and David Perrin. 2017. The challenges of managing degree apprentices in the workplace: A manager's perspective. Journal of Work-Applied Management 9: 185-99. [CrossRef]

Shury, Jan, David Vivian, Katie Gore, Camilla Huckle, and Vicki Belt. 2012. UK Commission's Employer Perspectives Survey 2012. UKCES Evidence Report 79. Wath-upon-Dearne: UKCES.

Small Enterprises Institute of the Hellenic Confederation of Professionals, Craftsmen and Merchants. 2017. Apprenticeship and Small Enterprises: Institutional Framework and Suggestions for the Improvement of the System. Athens: Small Enterprises Institute of the Hellenic Confederation of Professionals, Craftsmen and Merchants. (In Greek)

Winterbotham, Mark, David Vivian, Camilla Huckle, Andrew Skone James, Terence Hogarth, Lynn Gambin, and Chris Hasluck. 2012. Evaluation of Apprenticeships: Employers. BIS Research Paper Number 77. London: BIS/NAS. 